\title{
Effect of cultivar, tree vigour and fruit position on calcium accumulation in avocado fruits
}

\author{
G.W. Witney, P.J. Hofman* and B.N. Wolstenholme \\ Department of Horticultural Science, University of Natal, Pietermaritzburg (South Africa)
}

(Accepted for publication 8 February 1990)

\begin{abstract}
Witney, G.W., Hofman, P.J. and Wolstenholme, B.N., 1990. Effect of cultivar, tree vigour and fruit position on calcium accumulation in avocado fruits. Scientia Hortic., 44: 269-278.

The seasonal trends of calcium ( $\mathrm{Ca}$ ) in cultivars 'Fuerte' and 'Hass' avocado fruits from vigorous and non-vigorous trees with little and moderate root infection by Phytophthora cinnamomi, respectively, were studied. The Ca concentration increased in all fruit until 6 weeks after fruit set, but then decreased rapidly until $\sim 16$ weeks. Ca mass per fruit increased fairly consistently throughout fruit growth, except between Weeks 6 and 10 after fruit set, when a net export of Ca from the fruit occurred. 'Hass' fruit, and those from non-vigorous trees, contained significantly higher $\mathrm{Ca}$ concentrations and total mass of $\mathrm{Ca}$ per fruit than those from 'Fuerte', or from vigorous trees. This appeared to be related to less competition from the spring vegetative growth flush. Fruit position in the four quadrants did not influence fruit $\mathrm{Ca}$ concentration; however a significant correlation was shown between fruit $\mathrm{Ca}$ concentration and days to ripen. Management implications are discussed with a view to increasing fruit $\mathrm{Ca}$ for better post-harvest quality.
\end{abstract}

Keywords: avocado; calcium; fruit ripening; vigour.

\section{INTRODUCTION}

The mediatory role of calcium ions $\left(\mathrm{Ca}^{2+}\right)$ and of the Ca-binding protein calmodulin in plant development has been recognized in recent years, particularly its role as a "second messenger" and in cell wall and membrane function (Marme, 1983; Marme and Dieter, 1983; Smith, 1984; Hepler and Wayne, 1985; Poovaiah, 1985; Poovaiah et al., 1988). Shear (1975) listed 35 physiological disorders associated with $\mathrm{Ca}$ nutrition in fruits and vegetables. The best researched of these are bitterpit of apples and blossom-end rot of tomatoes. Other reviews (Atkinson et al., 1980; Himelrick and McDuffie, 1983; Smith, 1984; Poovaiah, 1985; Poovaiah et al., 1988) emphasize the Ca

*Present address: Queensland Department of Primary Industries, 19 Hercules Street, Hamilton, Qld., 4007, Australia. 
nutrition of target organs such as fruits, rather than whole plant nutrition. The general consensus from these reviews is that $\mathrm{Ca}^{2+}$ is very important in fruit quality.

It is generally agreed that Ca-related disorders arise mainly from internal Ca distribution problems, and its allocation between mature and growing regions of the plant. Most transport occurs by mass flow in the xylem and by chromatographic movement along $\mathrm{Ca}$ exchange sites in xylem walls. Competition between sinks is intensified when $\mathrm{Ca}^{2+}$ in xylem is low and transpiration high (Clarkson, 1984). Plants must be continuously supplied with $\mathrm{Ca}$ since little or no redistribution occurs to new growth zones after accumulation (Poovaiah, 1985).

Low avocado (Persea americana Mill.) fruit $\mathrm{Ca}$ levels have been associated with several undesirable fruit characteristics, e.g. rapid softening after harvest (Tingwa and Young, 1974; Wills and Tirmazi, 1982), susceptibility to chilling injury (Chaplin and Scott, 1980) and mesocarp disorders (Van Rensburg and Engelbrecht, 1985; Bower and Cutting, 1988). These are especially important to the South African avocado industry because the heavy dependence on overseas markets requires $\sim 4$ weeks sea transport, when premature ripening and mesocarp disorders are often observed (Ginsberg, 1985).

Several methods have been investigated to alleviate low avocado fruit $\mathrm{Ca}$ levels. For example, Veldman (1983) used orchard sprays of Ca $\left(\mathrm{NO}_{3}\right)_{2}$, but these were unsuccessful in controlling pulpspot (a mesocarp disorder). Postharvest fruit dips in various Ca salts suppressed respiration and polyphenol oxidase activity (Van Rensburg and Engelbrecht, 1985). Eaks (1985) found vacuum infiltration of avocado fruit with $\mathrm{Ca}$ solutions to be more effective than dips in delaying ripening and suppressing ethylene evolution and respiration; however, the former also adversely affected external fruit appearance.

This study was initiated by the need to identify cost-effective means of improving fruit quality and post-harvest storage life through an influence on fruit $\mathrm{Ca}$ accumulation. The only previous field study in this area is that of Bower (1985), but this focused primarily on long-term irrigation requirements. We hypothesized that early and vigorous onset of the spring vegetative growth flush would reduce $\mathrm{Ca}$ movement to fruitlets at a critical stage, especially in cultivar 'Fuerte'.

\section{MATERIALS AND METHODS}

The experiment was conducted in a commercial orchard near Pietermaritzburg (latitude $29^{\circ} 26^{\prime} \mathrm{S}$, longitude $30^{\circ} 18^{\prime} \mathrm{E}$ ), at an altitude $\sim 750 \mathrm{~m}$. The climate can be described as warm subtropical, with relatively low, predominantly summer rainfall of $\sim 750 \mathrm{~mm}$ per annum. The trees were grown on West Indian seedling rootstock in a typical oxisol (Hutton form, Farningham series) with $\sim 45 \%$ clay in the B 21 horizon. 
Twenty 'Hass' and 20 'Fuerte' trees were used. Ten trees of each cultivar were vigorous and apparently free of infection from Phytophthora cinnamomi root rot. The other 10 trees were classified as non-vigorous, and rated 4 on the 0 (vigorous and healthy)-10 (dead) scale widely used in Phytophthora research. Trees in each category were selected based on uniformity of fruit mineral composition, vegetative growth, flush timing, canopy density, crop load, canopy spread and height, and stage of flowering. They were also on the same soil form and series, generally on the same contour and away from orchard boundaries.

Harvesting commenced on 20 October (late spring), 2 weeks after peak fruit set. Samples (one fruit from each of 10 trees within each category) were collected initially at 2-week intervals, but this was increased to 3 weeks as fruit $\mathrm{Ca}$ concentration stabilized. Sampling was terminated after 25 weeks when fruits of both cultivars had $<80 \%$ moisture (Swarts, 1976) and were therefore "legally" mature. ("Hass fruits, however, would normally not be harvested for another 8 weeks or so.) Fruit were harvested between 8:00 and 10:00 $\mathrm{h}$ from the outer $0.5 \mathrm{~m}$ of canopy, between 1.5 and $3.0 \mathrm{~m}$ above ground, and at random from each quadrant of the tree. Ten fruits from each of the four categories of cultivar and vigour were collected, weighed, dried to constant mass at $80^{\circ} \mathrm{C}$, milled through a $0.5-\mathrm{mm}$ screen and stored in air-tight glass containers for subsequent analysis.

Fruits were individually analysed for Ca. Duplicate samples of $0.3 \mathrm{~g}$ were digested for $90 \mathrm{~min}$ at $400^{\circ} \mathrm{C}$ with $2.5 \mathrm{~g}$ catalyst powder (Kjeldahl pak), $3 \mathrm{ml}$ concentrated $\mathrm{H}_{2} \mathrm{SO}_{4}$ and $4 \mathrm{ml} \mathrm{H}_{2} \mathrm{O}_{2}$. Digested samples were made up to 100 $\mathrm{ml}$ with distilled water and analysed in an autoanalyser (Technicon II) using standard methods. Subsamples were checked using atomic absorption spectroscopy and were found to be within $10 \%$ of autoanalyser results.

As a measure of shoot growth activity, the percentage of shoots showing obvious vigorous extension growth was estimated every 2-3 weeks for each cultivar and vigour category. Meteorological readings of temperature and relative humidity (thermohygrograph) and rainfall were taken on a weekly basis.

The effect of aspect on fruit Ca concentration was determined by harvesting fruits on 15 May from one tree in each category from the northwest, northeast, southwest and southeast quadrants of the tree. Five fruits were taken from each category and quadrant. The fruits were stored at $20^{\circ} \mathrm{C}$ and the days to full softness (indicated as a reading of 100 on the firmometer described by Swarts, 1981) recorded. The fruits were then dried and Ca concentrations determined in each fruit as previously described.

Results were analysed as a randomized design, with single-tree and singlefruit replications for the former and latter experiments, respectively.

\section{RESULTS}

The mean Ca concentration ( $\mathrm{mg} \mathrm{kg}^{-1}$ dry mass (DM)), in 'Fuerte' and 'Hass' fruit from both vigorous and non-vigorous trees increased $(P=0.01)$ 


\section{TABLE 1}

Mean $\mathrm{Ca}$ concentration ( $\mathrm{mg} \mathrm{kg} \mathrm{kg}^{-1} \mathrm{DM}$ ) of 'Fuerte' and 'Hass' fruit from vigorous and nonvigorous trees. Data with the same letter are not significantly $(P=0.01)$ different

\begin{tabular}{ll}
\hline $\begin{array}{l}\text { Weeks after fruit } \\
\text { set }\end{array}$ & $\begin{array}{l}\text { Mean fruit Ca concentration } \\
\left(\mathrm{mg} \mathrm{kg}^{-1}\right)\end{array}$ \\
\hline 2 & $2596^{\mathrm{a}}$ \\
4 & $5020^{\mathrm{b}}$ \\
6 & $6230^{\mathrm{c}}$ \\
8 & $3330^{\mathrm{d}}$ \\
10 & $1974^{\mathrm{e}}$ \\
13 & $1631^{\mathrm{f}}$ \\
16 & $1393^{\mathrm{g}}$ \\
19 & $1214^{\mathrm{gh}}$ \\
22 & $1161^{\mathrm{h}}$ \\
25 & $1145^{\mathrm{h}}$ \\
\hline
\end{tabular}

$\operatorname{LSD}(P=0.01)=234.6$.

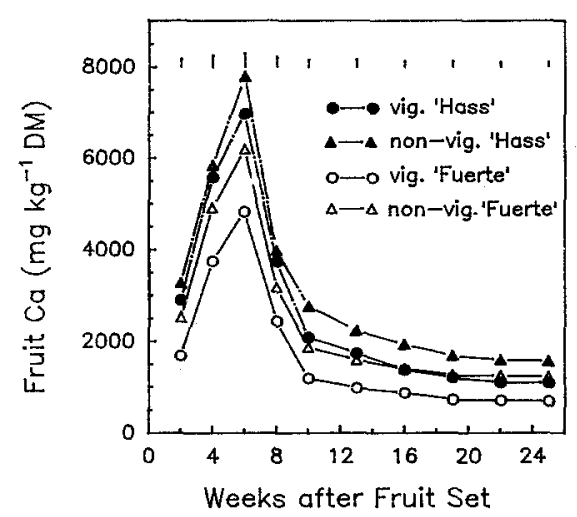

Fig. 1. Seasonal $\mathrm{Ca}$ concentration ( $\mathrm{mg} \mathrm{kg}^{-1} \mathrm{DM}$ ) in vigorous and non-vigorous 'Hass' and 'Fuerte' avocado fruit. Bars at the top of the figure indicate the LSD $(P=0.01)$ for each harvest date.

until 6 weeks after fruit set (Table 1). Concentrations then decreased rapidly until $\sim 11$ weeks, then more slowly to maturity, when concentrations were $<2000 \mathrm{mg} \mathrm{kg}^{-1}$. Therefore the most marked changes in fruit Ca concentration occurred in the first 11 weeks after fruit set.

Both cultivar and vigour significantly affected fruit $\mathrm{Ca}$ concentration (Fig. 1). At all harvests, 'Hass' fruit had higher concentrations than 'Fuerte', and fruit from non-vigorous trees had higher concentrations than that from vigorous trees. This was most obvious at 6 weeks when concentrations were at their highest. Concentrations ranged from a maximum of $4830-7790 \mathrm{mg} \mathrm{kg}^{-1}$ 


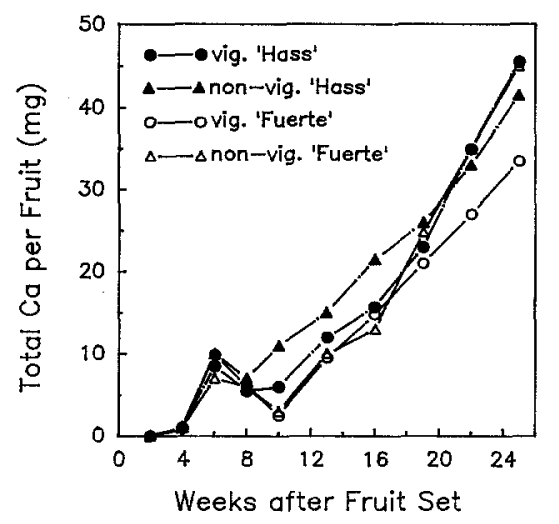

Fig. 2. Seasonal $\mathrm{Ca}$ accumulation (mg per fruit) in vigorous and non-vigorous 'Hass' and 'Fuerte' avocado fruit.

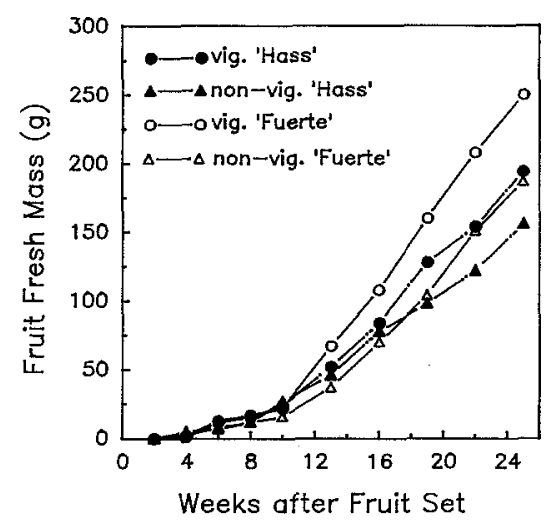

Fig. 3. Seasonal increase in mass $(\mathrm{g})$ of vigorous and non-vigorous 'Hass' and 'Fuerte' avocado fruit.

at 6 weeks to $690-1570 \mathrm{mg} \mathrm{kg}^{-1}$ at 25 weeks in non-vigorous 'Hass' and vigorous 'Fuerte', respectively.

Total fruit Ca mass in both cultivar and vigour categories increased rapidly to 6 weeks, decreased to 8 ('Hass') or 10 weeks ('Fuerte'), the consistently increased to maxima of 33-47 mg per fruit at 25 weeks (Fig. 2). This decline between 6 and 8 or 10 weeks corresponded to the rapid decline in Ca concentration (see Fig. 1). The increase in fruit $\mathrm{Ca}$ mass after this period was due primarily to increasing fruit mass (Fig. 3). Although vigorous 'Fuerte' fruit attained the greatest mass, their total Ca mass was the lowest because of the significantly lower Ca concentration in these fruit (see Fig. 1).

Two shoot growth flushes occurred during the analysis period (Fig. 4), as 


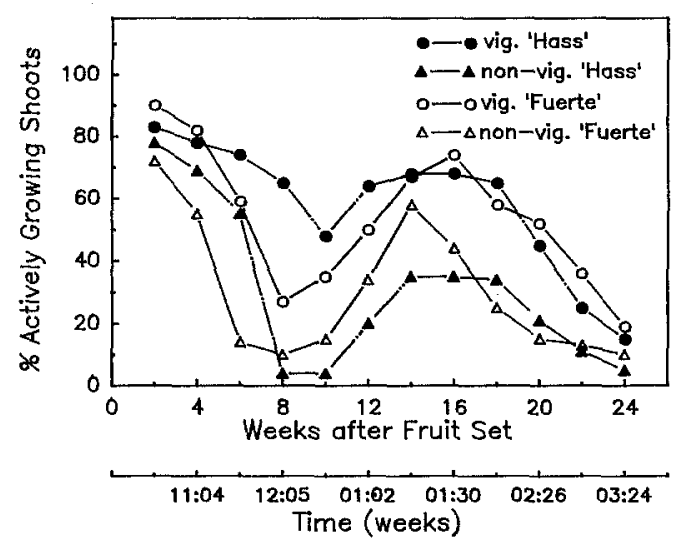

Fig. 4. Average percentage of actively growing shoots from vigorous and non-vigorous 'Hass' and 'Fuerte' trees during the fruit growth period.

\section{TABLE 2}

Mean Ca concentration ( $\mathrm{mg} \mathrm{kg}^{-1} \mathrm{DM}$ ) and days to ripen for 'Fuerte' and 'Hass' fruit from four quadrants on vigorous and non-vigorous trees. Data with the same letter within quadrant and tree type are not significantly $(P=0.01)$ different

\begin{tabular}{|c|c|c|c|c|c|c|c|}
\hline & & Aspect & NW & $\mathrm{NE}$ & SW & $\mathrm{SE}$ & Mean \\
\hline \multirow[t]{4}{*}{ 'Fuerte' } & Vigorous & $\mathrm{Ca}$ & $690^{a}$ & $660^{a}$ & $680^{\mathrm{a}}$ & $780^{b}$ & 702 \\
\hline & & Days & $9.2^{\mathrm{a}}$ & $9.0^{\mathrm{a}}$ & $9.0^{a}$ & $9.4^{\mathrm{a}}$ & 9.2 \\
\hline & Non-vigorous & $\mathrm{Ca}$ & $1100^{\mathrm{c}}$ & $1160^{\text {cde }}$ & $1140^{\mathrm{cd}}$ & $1160^{\text {cde }}$ & 1140 \\
\hline & & Days & $10.4^{\mathrm{b}}$ & $10.6^{\mathrm{b}}$ & $10.6^{\mathrm{b}}$ & $11.0^{\mathrm{bc}}$ & 10.7 \\
\hline \multirow[t]{4}{*}{ 'Hass' } & Vigorous & $\mathrm{Ca}$ & $1200^{\text {def }}$ & $1220^{\mathrm{ef}}$ & $1170^{\text {cde }}$ & $1250^{\mathrm{f}}$ & 1210 \\
\hline & & Days & $11.4^{\mathrm{cd}}$ & $11.6^{\mathrm{cd}}$ & $11.2^{\mathrm{cd}}$ & $11.8^{\mathrm{e}}$ & 11.5 \\
\hline & Non-vigorous & $\mathrm{Ca}$ & $1530^{\text {gh }}$ & $1590^{\mathrm{h}}$ & $1570^{\mathrm{gh}}$ & $1510^{\mathrm{g}}$ & 1550 \\
\hline & & Days & $13.6^{f}$ & $14.6^{\mathrm{g}}$ & $14.4^{\mathrm{g}}$ & $13.0^{\mathrm{f}}$ & 13.9 \\
\hline
\end{tabular}

$\operatorname{LSD}(P=0.01)=67(\mathrm{Ca}) ; 0.6($ days $)$.

is typical for mature avocado trees. The spring growth flush was more vigorous, and occurred during and after fruit set. The summer flush (January/ February) coincided with rapid fruit growth and was accompanied by a second drop of fruits. Vigorous trees had a greater percentage of actively growing shoots and flushing continued over a longer period. This resulted in vigorous trees having denser canopies and larger leaves than non-vigorous trees. Cultivar had little consistent effect on vegetative vigour, although 'Fuerte' is considered to be more vigorous and less fruitful than 'Hass'.

Fruit position had little consistent $(P=0.01)$ effect on Ca concentration or 


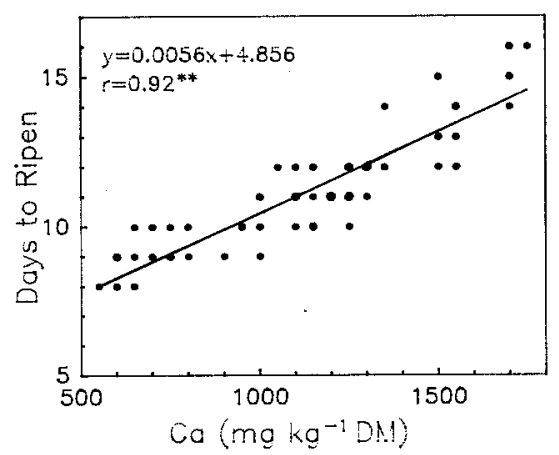

Fig. 5. Regression of days to fruit ripeness at room temperature on fruit Ca concentration. Data were obtained from both cultivar and vigour categories.

days to ripen (Table 2), with the $F$ test indicating no significant $(P=0.05)$ differences between quadrant means. However, both cultivar and vigour had highly significant $(P=0.01)$ effects, thus confirming the previous results. Regression analysis (Fig. 5) confirmed a significant $(P=0.01)$ influence of fruit $\mathrm{Ca}$ concentration on days to ripen at room temperature. For example, softening took $\sim 8$ days when fruit Ca was $<600 \mathrm{mg} \mathrm{kg}^{-1}$, to $>14$ days at $\sim 1700 \mathrm{mg} \mathrm{kg}^{-1}$, i.e.a 6-day increase in shelf life.

\section{DISCUSSION}

$\mathrm{Ca}$ accumulation into plant organs is thought to occur through two main mechanisms. Probably the most important is mass flow in the transpiration stream to the organ (Marschner, 1983). Thus tissues with greater evapotranspiration will generally accumulate more $\mathrm{Ca}$. The second is dependent on polar indoleacetic acid (IAA) transport from the organ (Bangerth, 1979), so that organs which are physiologically more active are more likely to show greater IAA export, and therefore increased $\mathrm{Ca}$ accumulation. Little re-allocation of accumulated Ca occurs, irrespective of the transport mechanism (Poovaiah, 1985). The present results can be explained in the light of these observations.

Ca concentration and mass per fruit showed identical seasonal patterns in both cultivar and vigour categories. Similar changes in $\mathrm{Ca}$ concentration have been observed in 'Fuerte' avocado (Bower, 1985) and in apples (Quinlan, 1969; Tromp, 1979). The rapid increase during the first 6 weeks is probably due to the relatively large transpirational loss because of the greater surface area:volume ratio at this age and, probably to a lesser extent, IAA export from the developing fruit. The decrease in Ca concentration is primarily a result of 
an inability of the continuing $\mathrm{Ca}$ accumulation (as seen by the total $\mathrm{Ca}$ mass per fruit) to counteract the rapid increase in fruit mass. This is more pronounced in 'Fuerte' because of its larger fruit size.

The rapid decline in Ca mass per fruit between Weeks 6 and 10 indicates a net export of $\mathrm{Ca}$. Such $\mathrm{Ca}$ losses have been identified in other fruit (Wiersum, 1979), and obviously result from $\mathrm{Ca}$ demand from other tissues exceeding that of the fruit. Several factors may have contributed to this, including the reduction in the fruit surface area:volume ratio, a possible temporary reduction in IAA export from the fruit, or increased sink strength from other vegetative tissues, such as new shoot growth. The present investigation gives no indication of the causes for this trend. However, further research is warranted since a knowledge of the fate of this exported $\mathrm{Ca}$ may indicate ways of preventing its loss.

Vegetative vigour influenced fruit $\mathrm{Ca}$ through the presence of actively growing shoots in close proximity to the developing fruits. Increased vegetative vigour would result in a greater number (and possibly efficiency) of IAAproducing sites and therefore greater auxin export. In addition, the greater number of immature leaves (which typically exhibit greater transpirational loss per unit leaf area ) would result in relatively greater transpirational flow to vegetative organs in the vigorous trees. The developing leaves would also have a higher demand for structural $\mathrm{Ca}$. It was also noted that the vigorous trees produced a greater number of indeterminate fruit and these would be more exposed to competition by the vegetative flush. The cultivar effect could be explained by the fact that the 'Fuerte' trees were larger, with larger leaves and denser canopy, and this may have caused the lower $\mathrm{Ca}$ levels in their fruit.

It is difficult to state which of the two mechanisms of $\mathrm{Ca}$ accumulation is the more dominant in avocado fruit. Fruits from the northern side of the tree were exposed to greater radiation intensity and duration (in the southern hemisphere). This should have resulted in greater transpirational loss from these fruits. The fact that they did not contain significantly more $\mathrm{Ca}$ that fruits from other tree sectors suggests that $\mathrm{Ca}$ accumulation into avocado fruits may be more dependent on IAA export than mass flow. This would be particularly so with larger fruits.

Avocado fruit $\mathrm{Ca}$ status has been associated with various aspects of fruit quality, such as ripening rate and mesocarp disorders (Chaplin and Scott, 1980; Eaks, 1985; Bower and Cutting, 1988), and this has been supported by the present investigation. In addition 'Fuerte' fruit had lower Ca status than 'Hass', and it is 'Fuerte' which poses the greatest problems to the South African industry with respect to fruit quality and premature softening. Thus practical treatments should be identified to increase fruit $\mathrm{Ca}$ concentration. The prospects for orchard Ca sprays, although so far disappointing (Veldman, 1983 ), should be investigated further, particularly because of their success in apple production (Terblanche et al., 1979). Post-harvest Ca dips, although 
partially successful (Van Rensburg and Engelbrecht, 1985), may have undesirable side-effects (Eaks, 1985).

Breeding for a more ideal vegetative/reproductive balance (based on the above principles) would provide a longer term solution. A cultivar with lower vegetative vigour at flowering would reduce the diversion of $\mathrm{Ca}$ away from developing fruit, as well as reducing fluctuations in fruit set. The production of determinate fruit may also be important. In the short term, certain cultural practices could be introduced. Manipulation of irrigation and leaf $\mathrm{N}$ status to de-emphasize the spring flush could be beneficial. Nitrogen form may also be important, since $\mathrm{NH}_{4}^{+}-\mathrm{N}$ has been shown to reduce Ca uptake in apples, compared to $\mathrm{NO}_{3}^{-}-\mathrm{N}$ (Fukumoto and Nagai, 1983). Thus avocado growers, who have applied mainly $\mathrm{NH}_{4}^{+}-\mathrm{N}$ fertilizers, partly as an aid in $P$. cinnamomi control (Pegg, 1976), may have inadvertently aggravated fruit Ca problems. There is also evidence that high soil Ca status, achieved by organic mulching and liming, has many benefits in avocado orchards (Broadbent and Baker, 1974), and may also contribute toward favourable $\mathrm{Ca}$ movement to fruit. Finally, the potential of foliar applications of growth retardants (e.g. paclobutrazol) to temporarily suppress spring vegetative growth (Wolstenholme et al., 1990) and thereby increase fruit $\mathrm{Ca}$ levels, requires further investigation.

\section{ACKNOWLEDGEMENTS}

This research was largely supported by a Hans Merensky Foundation bursary awarded to the senior author, on whose farm the research was conducted. Financial assistance was also received from the University of Natal Research Fund.

\section{REFERENCES}

Atkinson, D., Jackson, J.E., Sharples, R.O. and Waller, W.M. (Editors), 1980. Symposium on Mineral Nutrition and Fruit Quality of Temperate Zone Fruit Trees. Butterworth, Kent, 435 pp.

Bangerth, F., 1979. Calcium-related physiological disorders of plants. Annu. Rev. Phytopathol., 17: 97-122.

Bower, J.P., 1985. The calcium accumulation pattern in avocado fruit as influenced by longterm irrigation regime. S. Afr. Avocado Grow. Assoc. Yearb., 8: 97-99.

Bower, J.P. and Cutting, J.G., 1988. Avocado fruit development and ripening physiology. Hortic. Rev., 10: 229-272.

Broadbent, P. and Baker, K.F., 1974. Behaviour of Phytophthora cinnamomi in soils suppressive and conducive to root rot. Aust. J. Agric. Res., 25: 121-137.

Chaplin, G.R. and Scott, K.J., 1980. Association of calcium in chilling injury susceptibility of stored avocados. HortScience, 4: 514-515.

Clarkson, D.T., 1984. Calcium transport between tissues and its distribution in the plant. Plant Cell Environ., 7: 449-456. 
Eaks, I.L., 1985. Effect of calcium on ripening, respiratory rate, ethylene production, and quality of avocado fruit. J. Am. Soc. Hortic. Sci., 110: 145-148.

Fukumoto, M. and Nagai, K., 1983. Possible roles of calcium and ammonium in the development of bitter pit in apple. Physiol. Plant., 59: 171-176.

Ginsberg, L., 1985. Post harvest physiological problems of avocados. S. Afr. Avocado Grow. Assoc. Yearb., 8: 8-11.

Hepler, P.K. and Wayne, R.O., 1985. Calcium and plant development. Annu. Rev. Plant Physiol., 36: 397-439.

Himelrick, D.G. and McDuffie, R.F., 1983. The calcium cycle:uptake and distribution in apple trees. HortScience, 18: 147-151.

Marme, D., 1983. Calcium transport and function. In: A. Lauchli and R.L. Bielski (Editors). Encyclopedia of Plant Physiology, New Series, Vol 15. Springer-Verlag, Berlin, pp. 599-625.

Marme, D. and Dieter, P., 1983. Role of $\mathrm{Ca}^{2+}$ and calmodulin in plants. In: W.Y. Cheung (Editor). Calcium and Cell Function. Vol. 4. Academic Press, New York, pp. 263-311.

Marschner, H., 1983. General introduction to the mineral nutrition of plants. In: A. Lauchli and R.L. Bielski (Editors). Inorganic Plant Nutrition. Springer-Verlag, New York, pp. 5-60.

Pegg, K.G., 1976. Avocado root rot. In: Proceedings of the Avocado Field Day, Australian Avocado Growers Federation, 2 pp.

Poovaiah, B.W., 1985. Role of calcium and calmodulin in plant growth and development. HortScience, 20: 347-352.

Poovaiah, B.W., Glenn, G.M. and Reddy, A.S.N., 1988. Calcium and fruit softening: physiology and biochemistry. Hortic Rev., 10: 107-152.

Quinlan, J.D., 1969. Chemical composition of developing and shed fruits of Laxton's Fortune apple. J. Hortic. Sci., 44: 97-106.

Shear, C.B., 1975. Calcium-related disorders of fruit and vegetables. HortScience, 10: 361-365.

Smith, H. (Editor), 1984. Special issue: calcium. Plant Cell Environ., 7: 371-489.

Swarts, D.H., 1976. 'n Praktiese avokado-oliebepalingsmetode vir produsente. Citrus Sub-Trop. Fruit J., No. 511:8-11, 14.

Swarts, D.H., 1981. Fermometer - ondersoeke by avokados. S. Afr. Avocado Grow. Assoc. Yearb., 4: 42-46.

Terblanche, J.G., Woolbridge, L.G., Hesebeck, L.G. and Joubert, M., 1979. The redistribution and immobilization of calcium in apple trees with special reference to bitterpit. Commun. Soil Sci. Plant Anal., 10: 325-335.

Tingwa, P.D. and Young, R.E., 1974. The effect of calcium on the ripening of avocado fruit. J. Am. Soc. Hortic. Sci., 99: 540-542.

Tromp, J., 1979. The intake curve for calcium into apple fruits under various environmental conditions. Commun. Soil Sci. Plant Anal., 10: 325-335.

Van Rensburg, E. and Engelbrecht, A.H.P., 1985. Effect of calcium salts on the components causing browning of avocado fruits. S. Afr. Avocado Grow. Assoc. Yearb., 8: 88-91.

Veldman, G., 1983. Kalsiumnitraatebespuitings te Westfalia op avokados met die doel om pulpvlek te verminder. S. Afr. Avocado Grow. Assoc. Yearb., 6: 64-65.

Wiersum, L.K., 1979. Effects of environment and cultural practice on calcium nutrition. Commun. Soil Sci. Plant Anal., 10: 259-278.

Wills, R.B.H. and Tirmazi, S.I.H., 1982. Inhibition of ripening of avocados with calcium. Scientia Hortic., 16: 323-330.

Wolstenholme, B.N., Whiley, A.W. and Saranah, J.B., 1990. Manipulating vegetative:reproductive growth in avocado (Persea americana Mill.) with paclobutrazol foliar sprays. Scientia Hortic., 41: 315-327. 